\title{
Stage IV Retroperitoneal Sarcoma AJCC v8
}

National Cancer Institute

\section{Source}

National Cancer Institute. Stage IV Retroperitoneal Sarcoma A/CC v8. NCI Thesaurus.

Code C136819.

Stage IV includes: Any T, Any N, M1, Any G. M1: Distant metastasis. (AJCC 8th ed.) 